Primljen / Received: 16.7.2012.

Ispravljen / Corrected: 24.12.2012.

Prihvaćen / Accepted: 27.12.2012.

Dostupno online / Available online: 15.1.2013.

\section{Possibilities of underground engineering for the use of shallow geothermal energy}

Authors:

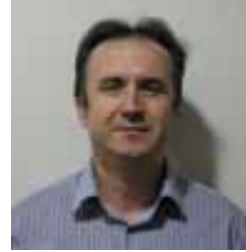

Prof. Meho Saša Kovačević, PhD. CE University of Zagreb

Faculty of Civil Engineering

Department for Geotechnical Engineering msk@grad.hr

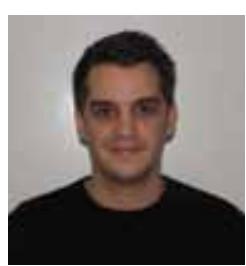

Mario Bačić

University of Zagreb

Faculty of Civil Engineering

Department for Geotechnical Engineering mbacic@grad.hr

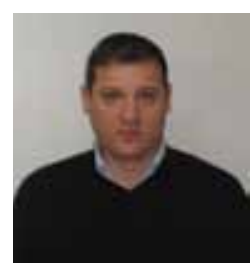

Ivan Arapov

University of Zagreb

Faculty of Civil Engineering

Department for Geotechnical Engineering arapov@grad.hr

\section{Meho Saša Kovačević, Mario Bačić, Ivan Arapov}

\section{Possibilities of underground engineering for the use of shallow geothermal energy}

Possible ways of using shallow geothermal energy, and capabilities of underground engineering in this process, are described in the paper. In addition to their basic role in ensuring bearing capacity or stability of soil and rock, reducing settlement of structures, etc., underground structures in direct contact with the soil, rock or groundwater can also be utilized as a part of geothermal systems where they can have an efficient role in the energy transfer process. In this case, they are referred to as "underground energy structures". The implementation of elements of underground structures as parts of geothermal systems is currently in its beginnings in Croatia.

\author{
Key words: \\ geothermal energy, underground engineering, underground energy structures
}

Pregledni rad

Meho Saša Kovačević, Mario Bačić, Ivan Arapov

\section{Mogućnosti podzemnog inženjerstva u iskorištavanju plitke geotermalne energije}

U radu se daje prikaz mogućih oblika iskorištavanja plitke geotermalne energije, te mogućnosti podzemnog inženjerstva u takvom procesu. Podzemne konstrukcije koje su u izravnom kontaktu s tlom, stijenom ili podzemnom vodom se osim svoje osnovne uloge u osiguranju nosivosti ili stabilnosti tla i stijene, reduciranju slijeganja konstrukcija, itd., mogu primijeniti i kao dio geotermalnih sustava gdje efikasno sudjeluju u procesu transfera energije. Njih tada nazivamo energetskim podzemnim konstrukcijama. U Hrvatskoj je implementacija elemenata podzemnih konstrukcija kao dijela geotermalnih sustava u svojim počecima.

Ključne riječi:

geotermalna energija, podzemno inženjerstvo, energetske podzemne konstrukcije

Übersichtsarbeit

Meho Saša Kovačević, Mario Bačić, Ivan Arapov

\section{Möglichkeiten des unterirdischen Ingenieurbaus in der Nutzung von geothermischer Energie}

In der vorliegenden Arbeit sind mögliche Formen der Nutzung von geothermischer Energie dargestellt und die Möglichkeiten des unterirdischen Ingenieurbaus in diesem Prozess erläutert. Unterirdische Strukturen, die in unmittelbarem Kontakt mit Boden, Fels oder Grundwasser errichtet sind, können neben ihrer grundlegenden Funktion, die Tragfähigkeit und Stabilität des Grundes zu sichern, die Setzung von Bauten zu reduzieren usw., auch als Bestandteile geothermaler Systeme genutzt werden, falls sie effizient dem Verlauf des Energietransfers beitragen. Diese werden dann als energetische unterirdische Strukturen bezeichnet. In Kroatien ist der Einsatz unterirdischer Bauwerke in geothermalen Systemen im Auftakt.

geothermale Energie, unterirdischer Ingenieurbau, energetische unterirdische Strukturen 


\section{Introduction}

The term "geothermal energy" denotes thermal energy that is generated and stored in the Earth. Geothermal energy can be generated in two ways. The first way is the result of formation of the Earth and radioactive decay of minerals in the Earth's core, while the second way in which the geothermal energy is generated is related to the direct action of solar energy that heats the surface portion of the Earth's crust. The possibility of using geothermal energy has been known to mankind since Palaeolithic when hot geothermal springs were used as baths, or for cooking [1]. Nowadays the use of geothermal energy is characterized by a wide array of potential applications, including generation of electricity, heating and cooling of residential and industrial facilities, heating greenhouses or animal farms, deicing roadways and airport runways, etc. Geothermal resources can be classified as shallow and deep, where the boundary between the two has been determined by the depth of $400 \mathrm{~m}$ [2]. The systems which utilize shallow geothermal resources are divided into open-loop and closedloop systems, and the latter can further be subdivided into horizontal and vertical systems, cf. Figure 1. Although, according to geologists, the term "geothermal energy" is still mostly related to deep resources of geothermal energy, the term is normally used in practice to denote all usable forms of thermal energy from the soil, rocks or groundwater.

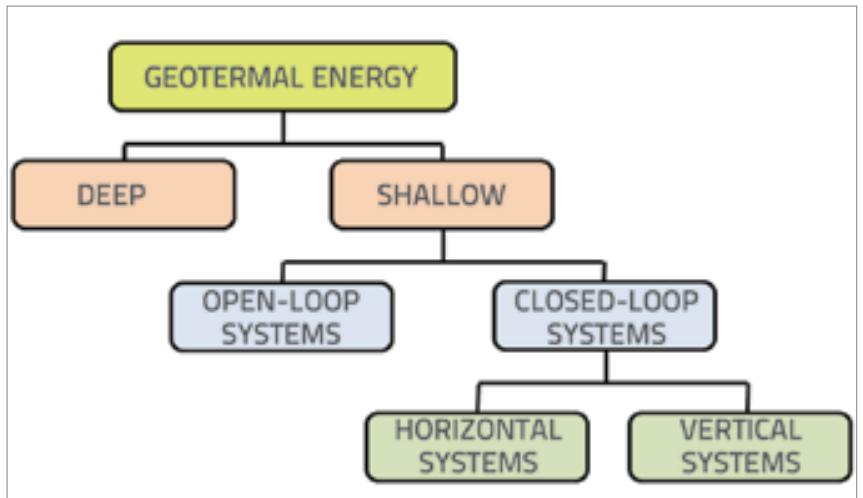

Figure 1. Classification of geothermal energy

The role of geothermal energy is quite significant in the future development of mankind and, in that respect, Maire et al. [3] state that geothermal energy is one of four main underground resources, including also the space, water and geomaterials, which lead to sustainable development of urban communities. The reason for this is that geothermal energy represents a very attractive source of energy that has numerous advantages when compared to conventional sources of energy such as coal, natural gas, and petroleum. The most significant advantage lies in the fact that it is a renewable and clean source of energy with no negative impacts on environment, unlike conventional non-renewable sources of energy [4]. The exploitation of geothermal energy also presents some economic advantages. A good example is the use of shallow geothermal resources for heating and cooling of buildings. Although initial costs of installing a geothermal system for the exploitation of shallow geothermal resources exceed by 20 to $50 \%$ the initial costs of installing conventional systems [5], the period of return of initial investment (payback period) amounts to no more than 3 to 8 years in EU countries [6]. This payback period is dependent on a number of parameters including inter alia characteristics of the geological medium that will be exploited, characteristics of the geothermal system installed, and the market price of energy.

Possible forms of exploitation of geothermal energy will be presented in the following text and, at that, a special emphasis will be placed on the possibility of using elements of underground structures as parts of geothermal systems. In fact, shallow exploitation of geothermal energy is based on the use of geothermal potential of soil, rock, or groundwater, which are in direct contact with elements of underground structures. Although such structures are primarily constructed to fulfil their basic roles (ensure bearing capacity of soil/rock, prevent soil collapse, ensure stability of underground openings in soil/rock, etc.), the use of these elements as integral parts of geothermal systems adds an additional significant dimension to their primary functions.

\section{Exploitation of deep geothermal resources}

The exploitation of geothermal resources situated more than $400 \mathrm{~m}$ in depth is based on the drilling of very deep boreholes. The idea of using the geothermal energy of the Earth was initially based on the known potential of deep geothermal resources characterized by high temperatures. Deep geothermal resources can be divided into hydrogeothermal deposits and hot dry rocks (HDR) [7]. It is in hot dry rocks, located at depths exceeding $1500 \mathrm{~m}$ and characterized by low permeability and porosity, that most deep geothermal resources are found in form of heat stored in rocks. Deep geothermal energy resources can be very efficient in the generation of electicity, and for heating of buildings. Geothermal resources with the temperature of more than $100^{\circ} \mathrm{C}$ are normally considered appropriate for the generation of electicity. The geothermal gradient of a particular location is of crucial significance for the exploitation of deep geothermal resources. This gradient defines an increase in temperature by depth, usually for $100 \mathrm{~m}$ intervals [8]. An average geothermal gradient at an international level amounts to $3^{\circ} \mathrm{C} / 100 \mathrm{~m}$. The exploitation of deep geothermal resources differs greatly from the exploitation of shallow ones, both in terms of technology used and market that is being targeted. A more detailed and thorough description will be given for shallow geothermal resources, as these resources are of greater significance for underground engineering. 


\section{Exploitation of shallow geothermal resources}

Systems used for the exploitation of shallow geothermal resources are designed for the exploitation of geothermal potential at the depths of less than $400 \mathrm{~m}$. These systems are most often used for heating and cooling and, as they are not based on exploitation of high-temperature geothermal resources, which is the case with deep exploitation systems, they are not considered efficient in the generation of electricity. The systems for the exploitation of shallow geothermal resources are based on the principle that the temperature of soil/rock and groundwater is constant throughout the year at a particular depth. In fact, the ground surface zone is subjected to direct influence of external weather conditions, and this influence decreases with an increase in depth, all the way down to the depth where the temperature is constant. A presentation of measured mean monthly soil temperatures to $100 \mathrm{~cm}$, with calculated values of soil temperature damping with the change in depth, as based on sine functions for the Zagreb - Maksimir site, according to Kurevija [9], is given in Figure 2.

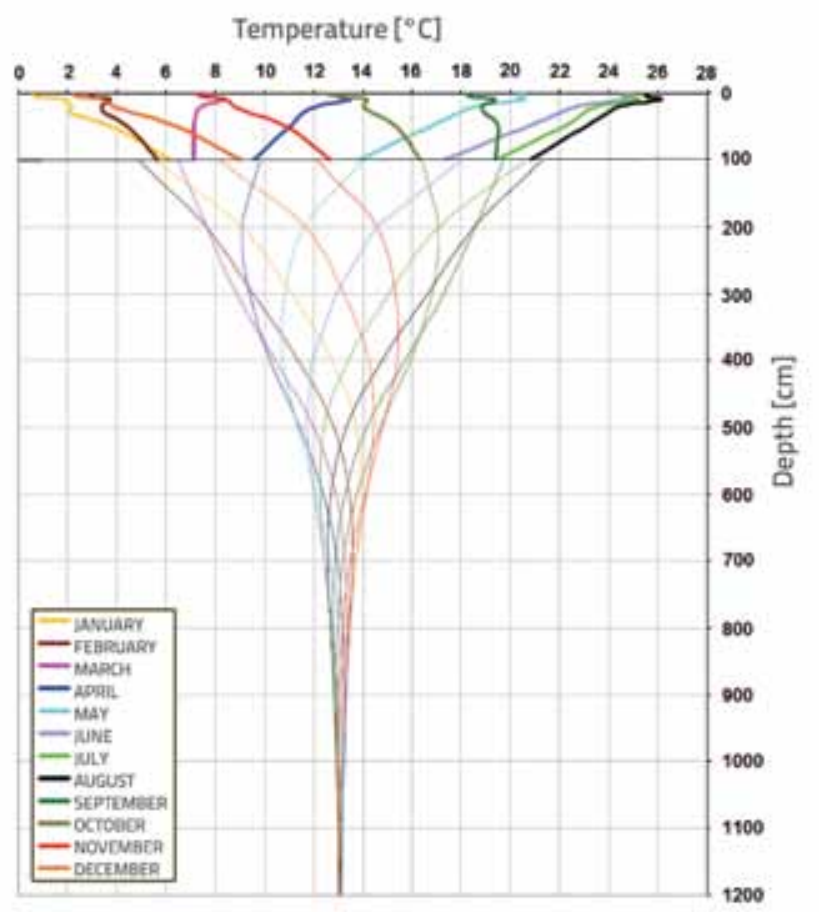

Figure 2. Curves shown changes in temperature across the depth, for the Zagreb area [9]

To enable full understanding of the principles relating to the use of various types of systems for exploitation of shallow geothermal resources, it is first of all necessary to explain the notion of the geothermal heat pump, which is the central part of every geothermal closed system. Its operating process will be presented below on heating example. The geothermal heat pump, Figure 3, is the system based on reversed Carnot's cycle, i.e. on the thermodynamic circular cycle, and its role is to convert work into heat. To enable realization of the cycle, the system must contain the working fluid which ensures heat transfer. Depending on the way in which the geothermal energy is used, the working fluid for the geothermal heat pump is either water or antifreeze (glycol) mixed with water. In order to prevent harmful environmental impacts, the use of CFC or other halogenated hydrocarbons was banned according to the Montreal Protocol (1987) and its subsequent revisions made in London (1990) and Copenhagen (1992) [10].

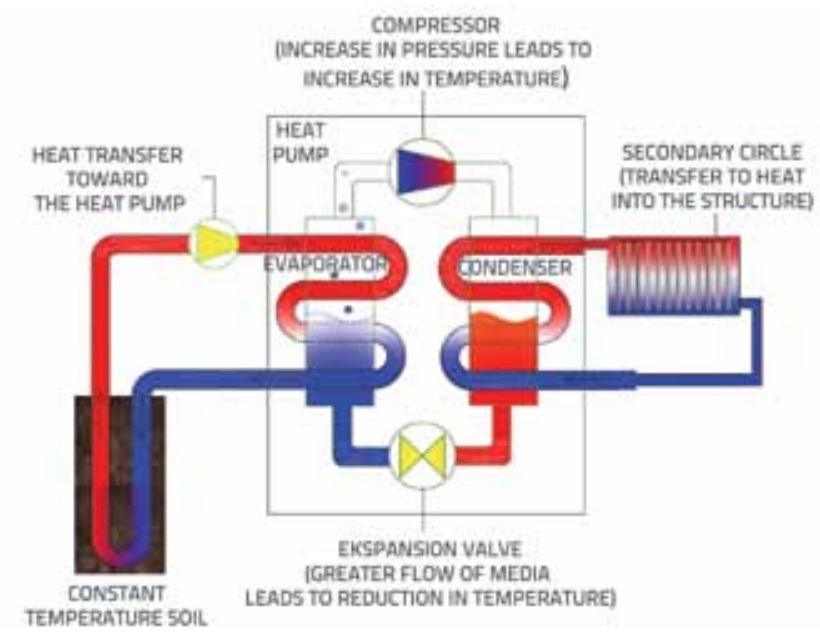

Figure 3. Operating principle of a geothermal heat pump

Basic components of a geothermal heat pump are: evaporator, compressor, condenser, and expansion valve. The thermal energy from the soil is transferred to the working fluid in the evaporator. Then the pressure is raised in the compressor so as to raise temperature of the working fluid to a higher energy level. After that, the working fluid reaches the condenser where the heat is released and used to heat the building. After the heat transfer, the working fluid reaches the expansion valve which marks the transition from the lower profile tube to a higher profile tube where the pressure of the working fluid (and hence also the temperature) decreases, so that the evaporator can once again receive thermal energy from the soil. The efficiency of heat pumps is most often expressed through the coefficient of performance (COP), which can be defined as the relationship between the pump's output power and electric energy needed for the operation of the heat pump. A higher COP value implies greater efficiency of the heat pump. However, the seasonal performance factor is better indicator of whole system efficiency (not just geothermal heat pump), as it correlates the total useful power produced with total power consumed for the operation of system in whole. This factor gives more accurate results with regard to operating costs incurred over the entire year. The high level of efficiency of geothermal systems is obtained by storing "heat surplus" in the summer period and using it in the winter 
period, and by storing "coldness surplus" in the winter period and using it during the summer period. The geothermal heat pump is connected with other parts of the geothermal system. These parts differ depending on the way in which shallow geothermal resources are exploited.

The systems for the exploitation of shallow geothermal resources are divided into open-loop systems and closed-loop systems. However, some shallow geothermal systems can not be strictly divided into open or closed loop systems. Here the best example would be the systems based on utilization of groundwater accumulated in abandoned mines $[11,12,13]$.

\subsection{Open-loop geothermal systems}

In open-loop systems, the groundwater is in fact the heat transfer medium. It should be noted that in this case water temperatures are lower than temperatures of hydrogeothermal water, so these systems are based on direct pumping of water from underground aquifers by means of a production well. Groundwater is pumped from aquifer and carried to the heat pump where the heat is extracted, and then the water is released into the aquifer by means of an injection well. In this way, a permanent circulation of the same quantity of working fluid (as in closed-loop systems) is avoided. If cooling is desired, the water that receives the heat is discharged into the aquifer. An open-loop geothermal system, with the production and injection wells that have to be located as far away as possible one from another, is presented in Figure 4.

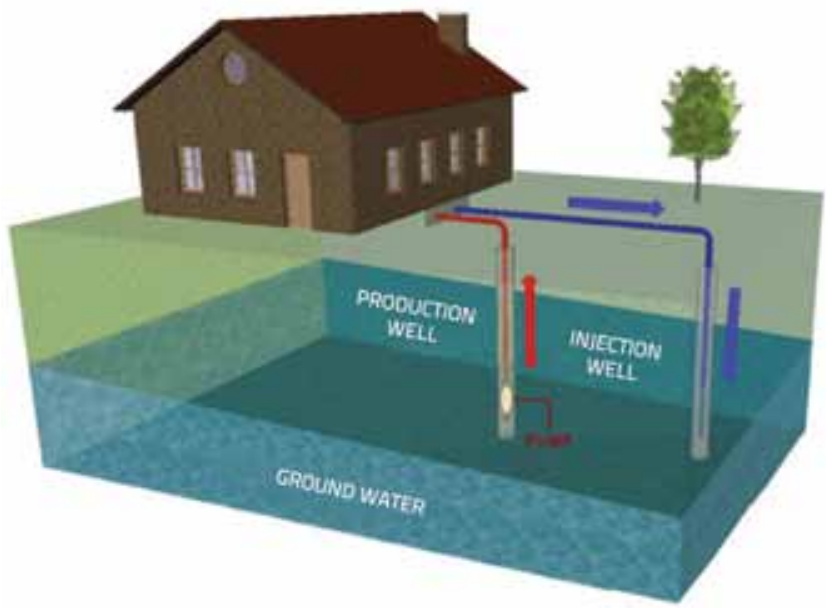

Figure 4. Open-loop geothermal system for the exploitation of shallow geothermal resources

Two basic requirements have to be met for an efficient and functional use of these systems: sufficiently permeable soil formations, and an appropriate chemical quality of groundwater [14]. In fact, in these systems, problems usually arise because of clogging resulting from deposition of dissolved minerals due to temperature changes, which is why it is important to use water with a low iron content. Instead of using injection wells, the water can also be released into surface waters (rivers, lakes, etc.).

\subsection{Closed-loop geothermal systems}

Closed-loop systems for the exploitation of shallow geothermal resources are based on the use of thermal potential of soil formations. Piping installations connected with the geothermal heat pump play an important role in this form of exploitation of geothermal energy. Pipes that are always filled with the same quantity of working fluid are mostly made of flexible and durable polyethylene or polybutene. They are used to conduct the working fluid through the soil or rock so as to enable the transfer of heat. According to the way in which these pipes are installed, closed-loop systems can be classified into horizontal and vertical systems.

\section{a) Horizontal closed-loop geothermal systems}

In horizontal systems, the pipes are placed into long trenches that are deeper than the frost line. Some possible pipe installation alternatives are horizontal straight (Figure 5a) and horizontal slinky (Figure 5b). Once pipes are placed, the trenches are backfilled. These systems are based on the fact that the soil heat generated by sun radiation is transferred to the working fluid in the pipes. As in this case pipes are placed relatively close to the ground surface, these systems are not efficient in areas with extreme weather conditions, where closed vertical systems are preferred.
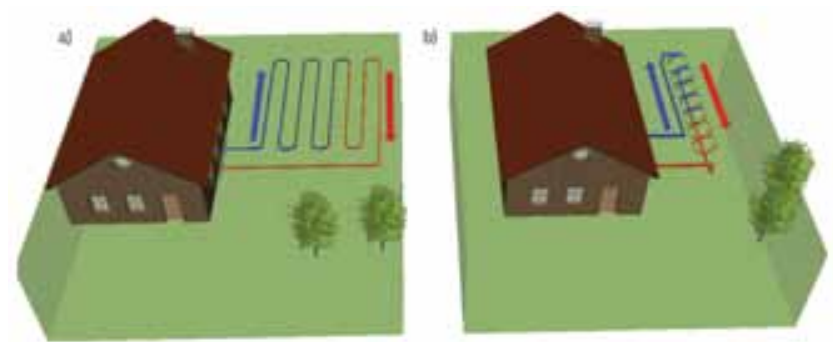

Figure 5. Horizontal closed-loop systems: a) horizontal straight pipe installation; b) horizontal slinky pipe installation

\section{b) Vertical closed-loop geothermal systems}

Other than being more efficient when compared to horizontal systems if installed in areas characterized by extreme temperatures, vertical closed-loop systems are also favourable when the pipe installation area is limited, or when utilizing geothermal potential of rock in which it would be hard to conduct excavation work for horizontal piping. In case of vertical closed-loop systems (Figure 6) the pipes are placed into a vertical borehole $150 \mathrm{~mm}$ in diameter, and are connected to the geothermal heat pump. 


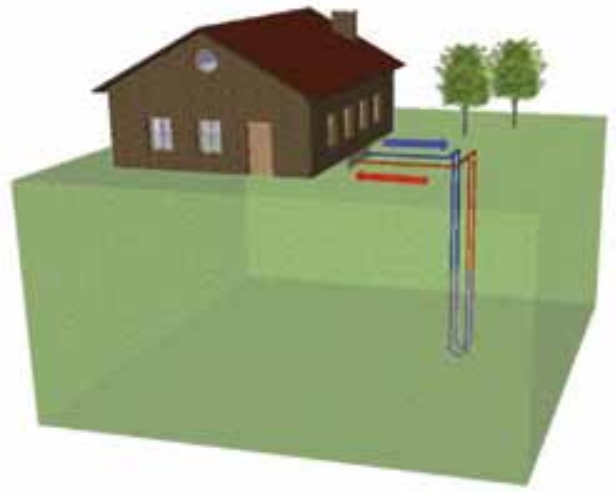

Figure 6. Vertical closed-loop geothermal system

The constant temperature of soil provides building heating in the winter period, Figure 7a, and building cooling in the summer period, Figure 7b.
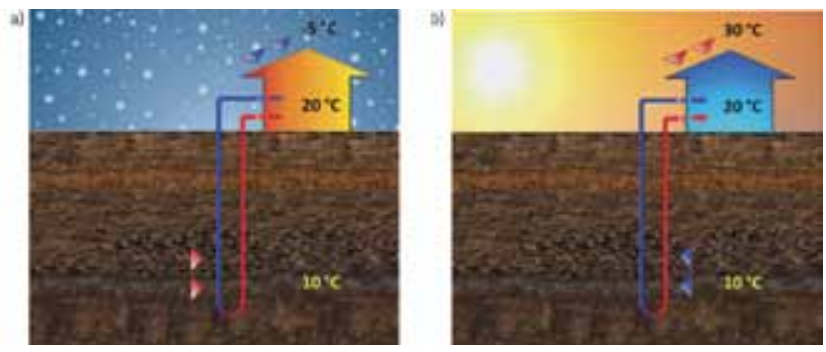

Figure 7. Vertical closed-loop system: a) heating in winter period; b) cooling in summer period

Pipes filled with working fluid can be positioned in several ways within the borehole, as shown in Figure 8. The most frequent pipe layout implies the use of the so called $U$ pipes, which obtained their name because of the fact that they turn at an angle of $180^{\circ}$ at the bottom of the borehole.
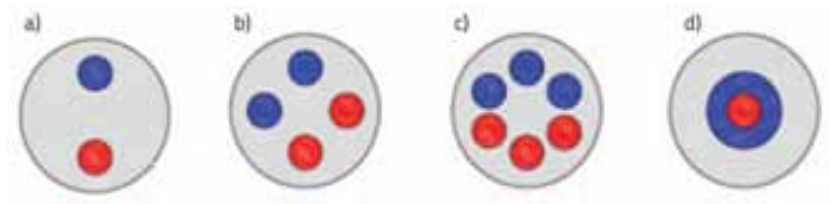

Figure 8. Pipe layout within the borehole: a) single $U$ pipe; b) double U pipe; c) triple U pipe; d) coaxial pipe

The space between pipes and the borehole wall is filled with grout so as to ensure an efficient heat transfer between the fluid in pipes and the surrounding soil/rock. In addition, borehole filling is important because it prevents vertical inflow of surface water, and potential pollution of the underground space. The thermal resistance of the borehole is highly important in the heat transfer process. It depends on the pipe layout within the borehole, and on thermal properties of the grout used. Grout mixtures most often used in this respect are either cement or bentonite based. Some studies have been made about possible use of grout mixtures based on fly ash, which is a by-product of industrial combustion of coal [15]. In addition, geothermal boreholes can also be filled with quartz sand.

\section{Role of underground structure elements as parts of geothermal systems}

Numerous research projects and, consequently, case studies, are based on the use of underground structure elements in the exploitation of geothermal energy. Foundation structures, retaining structures, concrete elements in tunnels, anchors and geosynthetics, they all have been used as parts of geothermal systems through which the heat is transferred in winter period from the soil and rock elements to the ground surface, while the reverse direction transfer is operated in summer period. This can be achieved by installing geothermal pipes, which contain fluid that is needed for heat exchange, into elements of underground structures. Thus, in addition to fulfilling their primary role, these elements are also used as heat exchangers in geothermal systems. Countries that can be considered as forerunners in this area are Austria, Germany and Switzerland, as they initiated these activities some three decades ago. An overview of possible uses of underground-structure elements as parts of geothermal systems will be presented in the following text, together with presentation of soil, rock and groundwater properties that are significant for the use of underground structures in the exploitation of geothermal energy.

\subsection{Classification of underground structures according to the use of geothermal energy}

Underground structures that form part of geothermal systems for exploitation of geothermal energy are referred to as energy structures, and so the distinction is made between energy foundation structures, energy support structures and energy tunnels.

\section{a) Energy foundation structures}

Foundation structures are the most frequently encountered underground energy structures. This group of structures is composed of piles of various cross sections, and foundation slabs. The primary role of these elements is to fulfil all safety and functional requirements of a particular structure, i.e. they have to limit settlements and prevent failure of the foundation soil. The piles, regardless of the way in which they are installed (bored, augered or driven), can be a part of the geothermal system and, in this case, they are referred to as energy piles. From the standpoint of use of geothermal energy, energy piles differ from each other in moment of pipe installation. In case of prefabricated driven piles, the pipes are installed in the factory, while in case of piles constructed on construction site, the pipes are attached to reinforcement cages. The piles are installed to the depth defined by the design and, at the bottom they are rotated for $180^{\circ}$, so that they assume the shape of 
the letter $\mathrm{U}$, cf. Figure 9. The pipes should be regularly arranged across the pile perimeter so as to optimize the heat transfer between the pipe and soil. Attaching pipes to reinforcement cages contributes to larger efficiency of the geothermal system because, in this case, pipes have a higher turning radius at the bottom, which results in higher flow of the working fluid when compared to installation of pipes in standard geothermal boreholes. After pipe installation and positioning, their integrity should be checked by introducing fluid under pressure. This is significant for bored piles as pipe damage can occur after the borehole is filled with concrete in which the reinforcement cage with pipes has already been installed. The pipe damage problem is even more pronounced in case of auger piles where the reinforcement cage with pipes is immersed into the borehole filled with concrete. In order to overcome any pipe integrity problems, the reinforcement cage should be as stiff as possible, and spiral reinforcement should be welded to vertical bars, instead of being tied to them with wire [10].

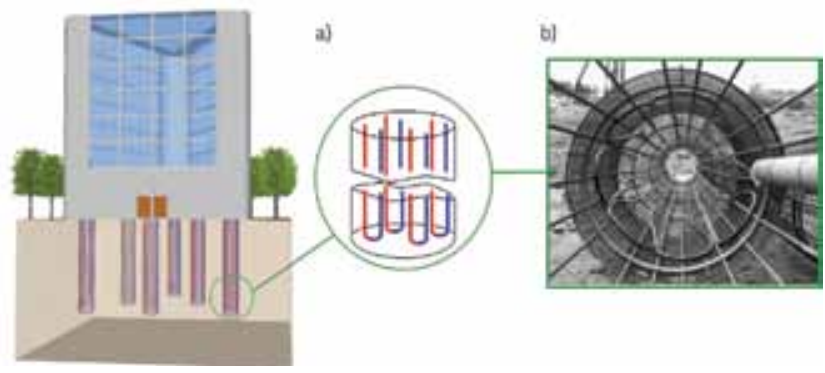

Figure 9. Energy piles: a) scheme of pipe position in pile: b) geothermal pipes attached to pile reinforcement [10]

At the surface, all pile pipes joined in header blocks which are connected to each other by a system of horizontal pipes. These horizontal pipes are most often located within the future foundation slab. There are many examples of research work and practical applications that are based on the possibility of using foundation systems in the exploitation of geothermal energy [10, 16-20].

\section{b) Energy support structures}

Support structures such as RC diaphragms, pile walls, and even various basement walls, play a crucial role in the lateral support of soil. They can be made of prefabricated elements or constructed on site. They can efficiently be used as parts of geothermal systems, where pipes are attached to the reinforcement of support elements [21]. In this case they are referred to as energy support structures. An example of such structures is shown in Figure 10 for the RC diaphragm that serves as protection during a deep excavation work. Katzenbach et al. [22] present the use of a pile walls in the exploitation of geothermal energy to provide heating for a structure in Frankfurt, where the foundation system is also used for this purpose.

\section{c) Energy tunnels}

The use of tunnels as parts of geothermal systems is based on installation of geothermal pipes within elements of the support system. The heat that is used for heating buildings does not only originate from the geothermal energy of soil, but is additionally generated from traffic passing through the tunnel tube. Besides the use of heat for heating buildings, this also has a significant positive influence on the cooling of the tunnel itself. Due to the fact that tunnels are linear structures that can measure several tens of kilometres in length, large volumes of soil or rock can be utilized in the geothermal energy exploitation process. A significant point for the utilization of tunnel elements is the tunnel overburden, i.e. the depth at which the tunnel is situated. Tunnels with higher overburden are located in highertemperature zones, which is the consequence of geothermal gradient. Several tunnelling technologies are available, and consequently there are several ways in which support systems can be utilized in the geothermal energy exploitation process.

The first tunnelling technology is the so called cut and cover method. This method is based on excavation of soil along the tunnel length, construction of tunnel elements, and backfilling these elements using the previously excavated soil. The formed tunnel structure is composed of vertical and

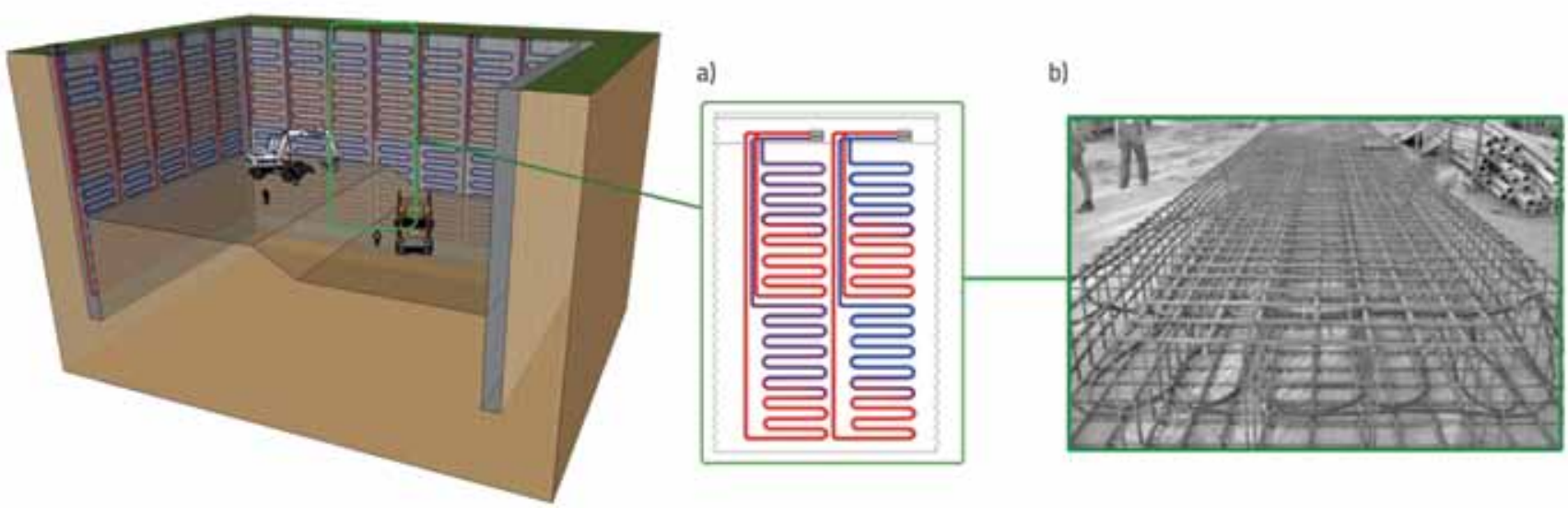

Figure 10. Energy RC diaphragm: a) scheme of pipe position in RC diaphragm; b) geothermal pipes attached to reinforcement of the diaphragm [10] 
horizontal elements. Vertical elements are RC walls or pile walls, while horizontal elements are RC slabs. Therefore, the installation of pipes for the use of geothermal resources is a well established procedure involving installation of pipes into foundations systems or support structures [23].

The second tunnelling technology consists in the use of special machines, the so called tunnel boring machines (TBM), for tunnel excavation in full profile. The excavation is made by means of a rotating cutting wheel called cutter head placed at the front side of the TBM. Once a predefined segment is excavated, support elements, i.e. prefabricated RC rings, are installed. These prefabricated rings can be utilized as a part of the geothermal system. After pipes are placed within ringshape segments, connected with the ring reinforcement, filled with working fluid and put into operation, it becomes possible to use the heat of soil, or the heat generated by tunnel traffic, to heat buildings situated on the ground surface. Pipes are connected to the ring reinforcement at the factory where the ring lining is filled with concrete mixture. The way in which pipes are installed into prefabricated rings is shown in Figure 11. This method for using geothermal energy is presented by Frodl et al. [24] on the example of the Jenbach Tunnel in Austria.

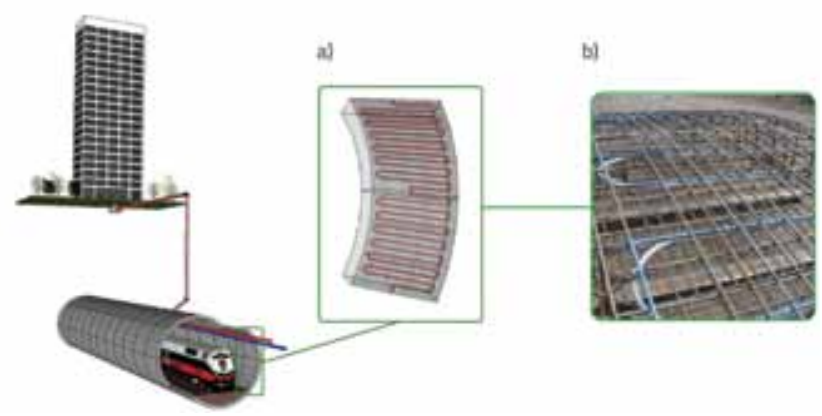

Figure 11. Energy tunnel built using the TBM method: a) installation of pipes into tunnel rings; b) geothermal pipes attached to the tunnel ring reinforcement [24]

The third tunnelling technology involves excavation and installation of the tunnel support system based on the New Austrian Tunnelling Method (NATM) or the Norwegian Method of Tunneling (NMT). Once a particular segment is excavated, various support system elements (anchors, concrete lining, steel arches, etc.) are installed. The primary role of these elements is to protect the tunnel opening from the cave-in of the surrounding rock/soil. These elements can efficiently be utilized as a part of geothermal systems, where pipes can be installed within the secondary RC lining of the tunnel. Furthermore, an interesting study on the use of tunnel anchors, called energy anchors, was conducted by Oberhauser [25]. An example of the use of geotextile, material that is not normally used in tunnelling, is presented by Adam et al. [26]. In this case, pipes are attached to the geotextile placed between the primary support system and secondary lining. A tunnel constructed using the NATM method is shown in Figure 12 where the position of pipes attached to the geotextile is marked, and the numerical model for testing thermal properties of energy anchors is shown.

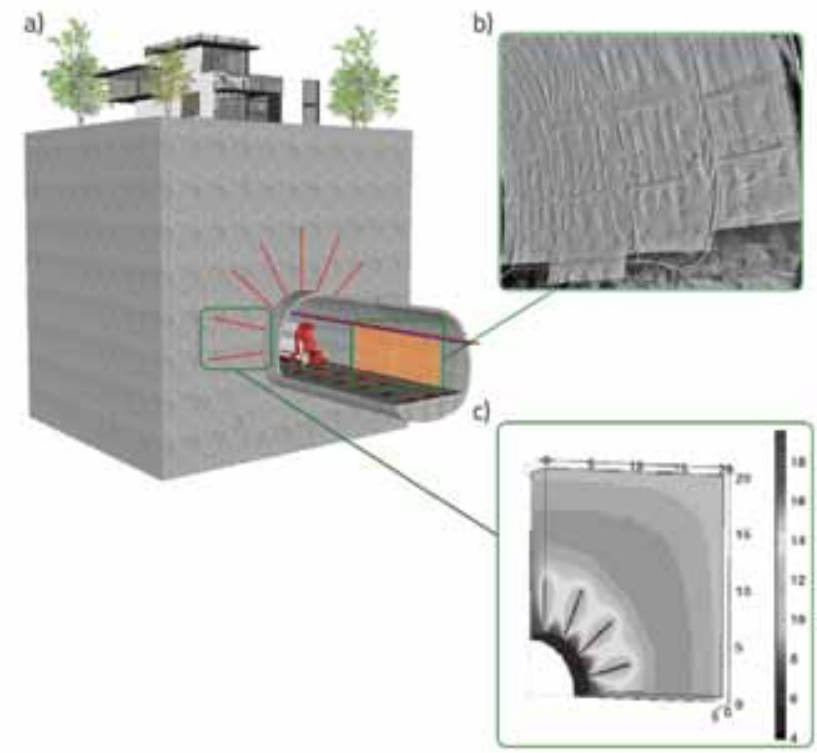

Figure 12. Energy tunnel built using the NATM method: a) tunnel diagram showing support elements; b) geothermal pipes attached to geotextile; c) numerical model for energy anchors [26]

An interesting example concerning the system in which geothermal energy is obtained by using tunnel drainage water is presented by Wilhelm et al. [27]. In fact, groundwater drainage into a tunnel opening after its excavation can be used for heating buildings, industrial plants and agricultural facilities. In addition, authorities are still considering the idea of using Paris Metro and its constant annual temperature of $14-20^{\circ} \mathrm{C}$ (due to traffic) for heating of residential buildings in poor districts [28]. Because of its length, the metro generates a large quantity of residual heat that could be carried, via heat exchangers, to heating systems in buildings.

\subsection{Parameters significant for the design of underground energy structures}

When discussing the utilization of elements of underground structures in the geothermal energy generation process, it should be noted that some geological medium have better properties than others. According to Brandl [6], about 20 $\mathrm{m}^{2}$ of area of concrete underground structures are needed to generate $1 \mathrm{~kW}$ of heat if such structures are situated in a saturated soil, or as much as $50 \mathrm{~m}^{2}$ if we wish to make use of geothermal potential in dry sand. As can be seen, the saturation plays a significant role in energy transfer. However, optimum conditions of the soil and groundwater change depending on the intended use of geothermal energy. If a geothermal system is used for heating only, or for cooling only, then it 
would be significant to have a soil with higher permeability, and groundwater with a higher hydraulic gradient. Higher velocity permeability and higher hydraulic gradient imply higher velocity of groundwater. If a geothermal system is used for both heating and cooling, that it would be significant to have soil with lower permeability and a lower hydraulic gradient. In this case, the soil is used as a heat storing medium. The process of heat transfer through soil is highly complex as it is composed of a number of mechanisms, primarily the conduction, but also radiation, convection, vaporization and condensation processes, ion exchange process and soil freezing and thawing processes. Brandl [10] presents an entire array of soil/rock and groundwater properties that influence the design of underground energy structures.

Inaddition to thealreadymentioned saturationand permeability, other geotechnical properties that are important for heat transfer are the soil/rock density and coefficient of porosity. If larger quantities of heat are needed to heat a building, it is very important to take into account the soil freezing and thawing effect. For instance, if foundation structures participate in the geothermal energy exploitation process, then soil temperature variations occurring as a consequence of heat transfer will not impact the bearing capacity of foundation structures as long as the soil temperature stays above $2^{\circ} \mathrm{C}$. However, decrease in temperature to $0^{\circ} \mathrm{C}$ may result in the freezing of foundation soil, which may cause loss of bearing capacity. It is also significant to take into account potential swelling and shrinking behaviour of soil that is to be used as the heat transfer medium. Of course, shear parameters for soil, and compressibility parameters, should also be taken into account when dimensioning energy foundation systems, all in order to enable fulfilment of their basic tasks relating to settlement reduction and providing sufficient bearing capacity. In addition, thermal properties of the soil/rock and groundwater are also significant for heat transfer. The thermal conductivity $(\lambda)$ and specific heat capacity (c) are the most significant thermal properties of the soil/rock and groundwater. They are defined during preliminary investigations based on the thermal response testing (TRT), during which the above parameters are determined in situ or by laboratory testing of samples. The thermal conductivity $\left(\mathrm{W} / \mathrm{m}^{\circ} \mathrm{K}\right)$ is the indicator of heat transfer from higher to lower sources of heat, and it strives toward temperature balancing, while the specific heat capacity $\left(\mathrm{J} / \mathrm{kg}^{\circ} \mathrm{K}\right)$ is defined as the quantity of energy that is needed to increase the temperature of a $1 \mathrm{~kg}$ mass for $1^{\circ} \mathrm{K}$, at a constant pressure. These parameters, together with the thermal diffusivity parameter $\left(\mathrm{a}, \mathrm{m}^{2} / \mathrm{s}\right)$ and specific gravity of soil or rock $\left(\rho, \mathrm{kg} / \mathrm{m}^{3}\right)$, form the basic equation describe thermal properties of soil/rock and groundwater:

$\lambda=a \cdot c \cdot \rho$

The heat transfer is also influenced by hydrogeologic properties, especially by the depth and seasonal variations of groundwater levels, and by their flow direction and velocity. In addition, mineralogical and geochemical properties of soil/ rock and groundwater are also important. All that has been mentioned so far is exclusively related to the properties of soil, rock and groundwater, and to phenomena occurring in them. However, the question of significant properties of underground elements participating as a part of geothermal energy transfer systems should also be considered. Significant properties include dimensions of elements, spacing between individual elements, element installation method, and properties of materials out of which these elements are made. Elements of underground structures are normally made of concrete or reinforced concrete. The thermal conductivity of concrete $\left(\lambda=1.6 \mathrm{Wm}^{\circ} \mathrm{K}\right.$ for $\mathrm{w} / \mathrm{c}=0.654$ and cement content of $300 \mathrm{~kg} / \mathrm{m}^{3}$ ) ensures a more efficient heat transfer when compared to a standard bentonite grout for geothermal boreholes $\left(\lambda=0.7 \mathrm{~W} / \mathrm{m}^{\circ} \mathrm{K}\right.$ at $\left.10^{\circ} \mathrm{C}\right)$.

\section{Geothermal energy in Croatia}

Croatian experience in the exploitation of geothermal energy is mostly based on the use of deep geothermal resources. This form of exploitation is especially attractive in the Pannonian Basin where the geothermal gradient is above the world's average, while Croatian Dinaric Alps, which account for more than $50 \%$ of the land area of Croatia [29,30], have the geothermal gradient that is lower than the world's average [31], Figure 13.

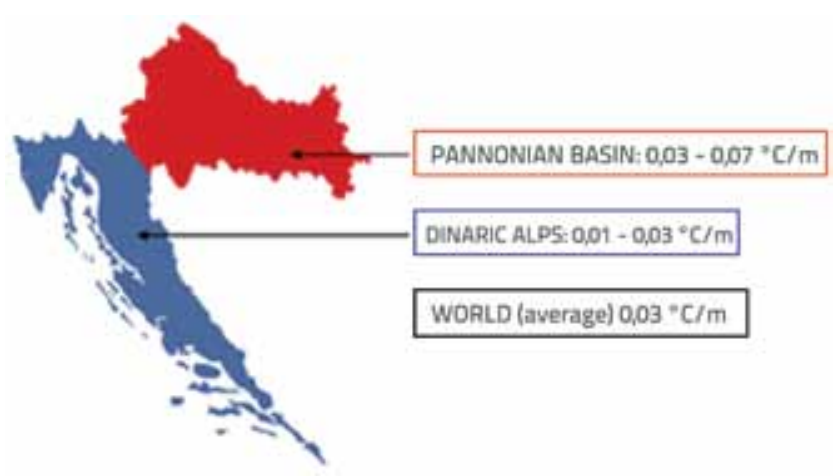

Figure 13. Geothermal gradient of Croatia

There are 28 geothermal reservoirs in Croatia, out of which 18 are currently in use. However, the total energy efficiency is very low [31]. Low temperature thermal waters are mostly used for medicinal and tourist purposes, while they are less used for heating man-made facilities. There are five geothermal fields with the temperature of more than $100^{\circ} \mathrm{C}$ in Croatia, and all of them are situated in the Pannonian Basin. The production of electricity from deep geothermal sources has still not been started in Croatia, but it is currently planned that as many as three geothermal plants will be realized in Croatia by the year 2020.

When discussing the use of shallow geothermal resources, it may be stated that vertical closed-loop geothermal systems 


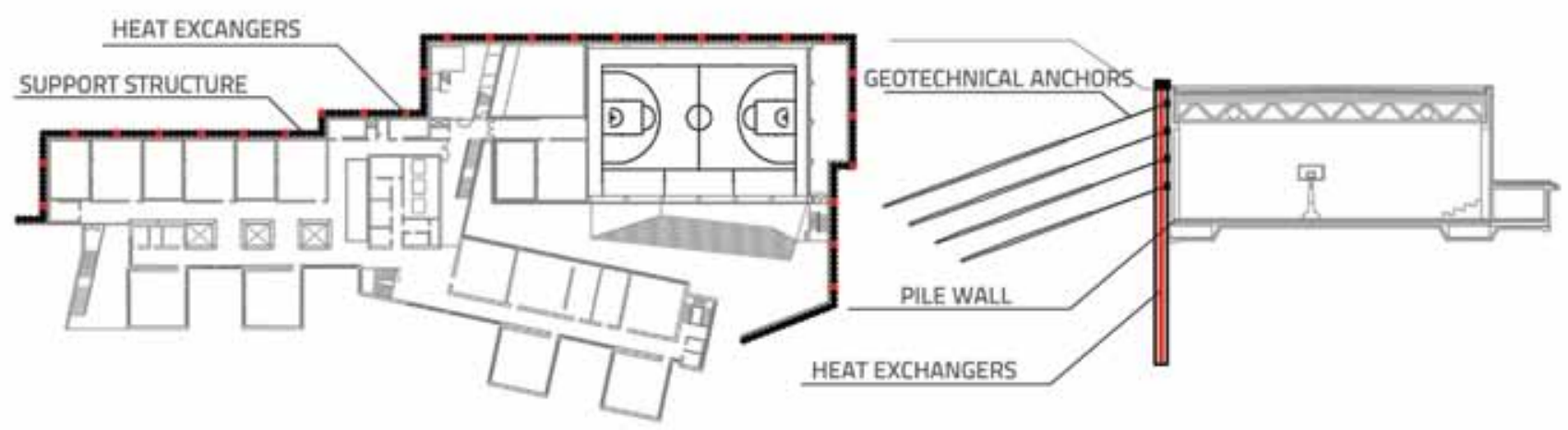

Figure 14. Plan view of heat exchanger positions, and typical cross section of the support structure for the Ksaver Šandor Gjalski Elementary School in Zagreb [32]

are most often used, and that the energy obtained in this way is used for heating and/or cooling heating and/or cooling purposes. However, there is still no underground structure in Croatia whose elements would be used as heat exchangers in geothermal systems. The International knowledge and experience relating to the use of underground structures in the exploitation of the geothermal potential has still not been implemented in Croatia. It should however be noted that the Centre for Shallow Geothermal Research was founded in 2010 in the scope of the Geotechnical Department of the Faculty of Civil Engineering, University of Zagreb, and that this initiative has given an additional impulse to establishment of closer ties between the geothermal energy and underground engineering.

The first pilot project aimed at using geothermal energy by means of underground structures is currently at the stage of preliminary design. A support structure, about $150 \mathrm{~m}$ in length, is to be constructed in the scope of the renovation and extension of the Ksaver Šandor Gjalski Elementary School in Zagreb. The support structure is designed as a RC pile wall, 20 $\mathrm{m}$ in height, which is additionally protected by geotechnical anchors. Faculty of Civil Engineering in Zagreb was requested from City of Zagreb to prepare a preliminary design, where mentioned support structure would be considered for geothermal energy utilization. The energy generated in this way would be used to heat the sports hall and its dressing rooms via a traditional floor heating system. Thus, a geothermal system has been designed at the preliminary design level in keeping with appropriate international standards (HRN EN 15450-2008 in particular), and based on the experience in the use of geothermal energy in the Republic of Croatia. According to its concept the system is a vertical closed-loop system, while the structure is an energy support system. The design solution is very simple: heat exchangers are installed in RC piles at $5 \mathrm{~m}$ intervals, i.e. in every sixth RC pile (Figure 14).

According to current experience in the installation of borehole heat exchangers, as gained in Zagreb County (oral exchange of information with contractors), about 50-60 W of specific energy efficiency per $\mathrm{m}$ ' of borehole can be obtained, which should results in the output power of $45-55 \mathrm{~kW}$. As the power requirements for heating the sports hall and its dressing rooms amount to about $150 \mathrm{~kW}$, it will be necessary to build a double heating system (floor heating + valve convectors). It should be noted that the cooling of the facility by borehole heat exchangers has not been considered (as this would certainly reduce the heat capacity of foundation soil in the long run, due to fall in temperature) because such possibility was not required.

In addition to this solution, an additional geothermal system alternative was proposed. According to this alternative solution heat exchangers, $100 \mathrm{~m}$ in individual length, would be installed, and hence the use of a double heating system would be avoided. At first $20 \mathrm{~m}$ heat exchangers would be installed in RC piles, and then they would be constructed as traditional borehole heat exchangers. This combined geothermal system would be a unique way of geothermal energy exploitation. The second solution would result in 185-225 kW of output power, which is more than sufficient for meeting power requirements for the sports hall and dressing rooms at the Ksaver Šandor Gjalski Elementary School.

\section{Conclusion}

The geothermal energy is a renewable source of energy that presents numerous advantages when compared to traditional sources of energy. In practical terms, the underground engineering is primarily interested in the utilization of shallow geothermal resources as it is precisely in this segment that underground structures can efficiently be used as parts of geothermal systems. A number of international research endeavours, and many successfully realized projects, involve the use of foundations structures, support structures and tunnels for exchanging heat with the soil, rock or groundwater. During design of such structures, all parameters relating to their basic role in ensuring bearing capacity and stability of structures, including also their energy transfer potential, must be taken into 
account. For that reason, designers should take into account geotechnical, thermal, hydrogeological, mineralogical and geochemical properties of soil/rock and groundwater, and dimensions of elements of underground structures, spacing between elements of underground structures, the way in which these elements are installed, and properties of materials these elements are made of. In Croatia, the use of such underground energy structures has not as yet found its place in the research and practical implementation. The first pilot project, in the scope of which an underground structure in Croatia will be used as a part of a geothermal system, is currently at the stage of preliminary design. The project involves the use of a pile wall that would additionally serve as heat exchanger, and its objective is to meet heating requirements of the sports hall and dressing rooms at the Ksaver Šandor Gjalski Elementary School in Zagreb.

\section{REFERENCES}

[1] Cataldi, R: Review of historiographic aspects of geothermal energy in the Mediterranean and Mesoamerican areas prior to the Modern Age, Geo-Heat Centre Quarterly Bulletin 15 (1993) 1، 13-16

[2] Haehnlein, S.; Bayer, P.; Blum P.: International legal status of the use of shallow geothermal energy, Renewable and Sustainable Energy Reviews 14 (2010), 2611-2625

[3] Maire, P.; Bluiner, P.; Parriaux, A.; Tacher, L.: Underground planning and optimisation of the underground ressources combination looking for sustainable development in urban areas, Workshop - Going Underground: Excavating the Subterranean City, Manchester (2006), 15 p.

[4] Fridleifsson, I.B.: Geothermal energy for the benefit of the people, Renewable and Sustainable Energy Reviews 5 (2001) 3, 299-312

[5] Watzlaf, G.R.; Ackman, T.E.: Underground Mine Water for Heating and Cooling using Geothermal Heat Pump Systems, Mine Water and the Environment 25 (2006) 1, 1-14

[6] Brandl, H: Geothermal heating and cooling of buildings, Zbornik 4. Šukljetovi dnevi, Portorož (2003), 3-27

[7] Rybach, L.; Bodmer, P.; Pavoni, N.; Mueller, St.: Siting criteria for heat extraction from hot dry rocks: application to Switzerland, Pure Appl. Geophys. 116 (1978), 1211-1224

[8] Šestanović, S: Osnove geologije i petrografije, Građevinski fakultet Sveučilišta u Splitu, 2001.

[9] Kurevija, T.: Energetsko vrednovanje plitkih geotermalnih potencijala Republike Hrvatske, Doktorski rad, Rudarsko Geološko - Naftni fakultet Sveučilišta u Zagrebu (2010), 183 p.

[10] Brandl, H.: Energy foundations and other thermo-active ground structures, Geotechnique 56 (2006) 2, 81-122

[11] Hall, A.; Scott, J.A.; Shang, H.: Geothermal energy recovery from underground mines, Renewable and Sustainable Energy Reviews 15 (2011) 916-924

[12] Raymond, J.; Therrien, R.; Hassani, F.:Overview of Geothermal Energy Resources in Québec (Canada) Mining Enviroments, Proceedings of 10th International Mine Water Association Congress, Karlsbad (2008), 99-110

[13] Wieber, G.; Pohl, S.:Mine Water:A Source of Geothermal Energy - Examples from the Rhenish Massif, Proceedings of 10th International Mine Water Association Congress, Karlsbad (2008), 113-116

[14] Sanner, B.: Shallow Geothermal Energy, Geo-Heat Centre Quarterly Bulletin 22 (2001) 2, 19-25
[15] Allan, M.; Philippacopoulos, A.: Performance Characteristics and Modelling of Cementitious Grouts for Geothermal Heat Pumps, Proceedings World Geothermal Congress, Kyushu - Tohoku (2000), 3355-3360

[16] Brandl, H.: Energy piles for heating and cooling of buildings, Proceedings of 7 th Int. Conf. Exhib. Piling and Deep Foundations, Vienna (1998), 341-346

[17] Suckling, T. P.; Smith, P.: Environmentally friendly geothermal piles at Keble College, Oxford, UK, Proceedings of 9th Int. Conf. Exhib. on Piling and Deep Foundation, Nice (2002), 445-452

[18] Laloui, L.; Moreni, M.; Vulliet, L.: Behavior of a dual-purpose pile as foundation and heat exchangers, Can Geotech J 40 (2003), 388-402

[19] Hamada, Y.; Saitoh, H.; Nakamura, M.; Kubota, H.; Ochifuji, K.: Field performance of an energy pile system for space heating, Energy and Buildings 39 (2007) 5, 517-524

[20] Gao, J.; Zhang, X.; Liu, J.; Li, K.; Yang, J.: Numerical and experimental assessment of thermal performance of vertical energy piles: An application, Applied Energy 85 (2008) 10, 901-910

[21] Xia, C.; Sun, M.; Zhang, G.; Xiao, S.; Zou, Y.: Experimental study on geothermal heat exchangers buried in diaphragm walls, Energy and Buidings 52 (2012), 50-65

[22] Katzenbach, R.; Clauss, F.; Waberseck, T.; Wagner, I.: Coupled Numerical Simulation of Geothermal Energy Systems, Proceedings of 12th International Conference ofIACMAG, Goa (2008), 1170-1179

[23] Unterberger, W.; Hofinger , H.; Grünstäudl, T.; Adam, A.; Markiewicz, R.: Utilization of Tunnels as Source of Ground Heat and Cooling - Practical Applications in Austria, Proceedings of the ISRM International Symposium 3rd ARMS, Kyoto (2004), 421-426

[24] Frodl, S.; Franzius, J. N.; Bartl, T.: Design and construction of the tunnel geothermal system in Jenbach, Geomechanics and Tunnelling 3 (2010) 5, 658-668

[25] Oberhauser, A.: Verfahrens und Komponentenentwicklung zur Planung von Tunnelthermie -Anglen, Doktorski rad, Vienna University of Technology (2006)

[26] Adam, D.; Markiewicz, R. Energy from earth-coupled structures, foundations, tunnels and sewers, Geotechnique 59 (2009) 3, 229-236

[27] Wilhelm, J.; Rybach, L.: The geothermal potential of Swiss Alpine tunnels, Geothermics 32 (2003) 4-6, 557-568

[28] Vrančić, T.: Građevine u svijetu - Zgrada grijana tjelesnom toplinom,Gradevinar 63 (2011) 12, 1133-1140 
[29] Kovačević, M.S.; Jurić-Kaćunić, D; Simović, R.: Određivanje modula deformacije karbonatnih stijena u hrvatskom kršu, Građevinar 63 (2011) 1, 35-41

[30] Garašić M; Kovačević M.S.; Jurić-Kaćunić D.: Investigation and remediation of the cavern in the vrata tunnel on the Zagreb Rijeka highway (Croatia), Acta carsologica 39 (2010), 61-77
[31] Jelić, K.; Kovačić, M.; Koščak-Kolin, S.: State of the Art of theGeothermal Resources in Croatia in the Year 2004, Proceedings of World Goethermal Congress 2005, Antalya (2005), pp. 9

[32] Kovačević, M.S.: Idejno rješenje: Geotermalni projekt, Gradevinski fakultet IR-GTP-125-2012, ožujak 2012. 